\title{
Latinitas Goes Native: The Philological Turn and Jacob Grimm's De desiderio patriae (1830)
}

\author{
Joep Leerssen
}

The period 1750-1850 has been described by the great German historian Reinhart Koselleck as the Sattelzeit: a watershed between two historical paradigms, in which social, cultural and conceptual changes co-occurred and mutually reinforced each other. ${ }^{1}$ Notions of society, time, culture, and the position of the individual in all of these, underwent fundamental alterations. Although Koselleck worked mostly in social and conceptual history, the concept of the Sattelzeit is also useful in literary history, to clarify the simultaneous rise of Romanticism, of historicism (also in the writing of history and of literary history) and of the modern philologies.

As I have argued elsewhere, the Sattelzeit witnesses the emergence of what we call 'national literatures' in Europe. ${ }^{2}$ Whereas the concept of literature in Classicism and the early Enlightenment was predicated on a universalist, transhistorical hypercanon (with Homer, Virgil, Horace, Tacitus, Cicero, Dante (Fig. 11.1), Camões, Cervantes and Shakespeare all simultaneously present), a 'philological turn' occurs after 176o. Literature (until then almost a singulare tantum, like 'milk' or 'guilt', referring to 'the condition of being literate') turned into a countable plural of literatures, distinguished either as to their period of production (to begin with, 'ancient' or 'modern') or, crucially, as to the language of their expression. While, in the words of Jorge Luis Borges, the classicist concept, with its undifferentiated notion of literature, had regarded the plurality of peoples and periods as mere incidentals, the new paradigm turned diversity of period and language into its central taxonomic criterion. ${ }^{3}$

At the same time, we see, in the philologies, the rise of the 'modern philologies' alongside the older classical studies. Exemplary transitional figures are Karl Lachmann (1793-1851) and Angelo Mai (1782-1854). Lachmann used his formidable textual scholarship, method, and reputation, acquired in the

1 Koselleck: 'Über die Theoriebedürftigkeit der Geschichtswissenschaft'.

2 Leerssen, National Thought in Europe.

3 "Para el concépto clásico, la pluralidad de los tiempos y de los hombres es acesoria. La literatura es siempre una sola." Quoted in my 'Literary Historicism'. 


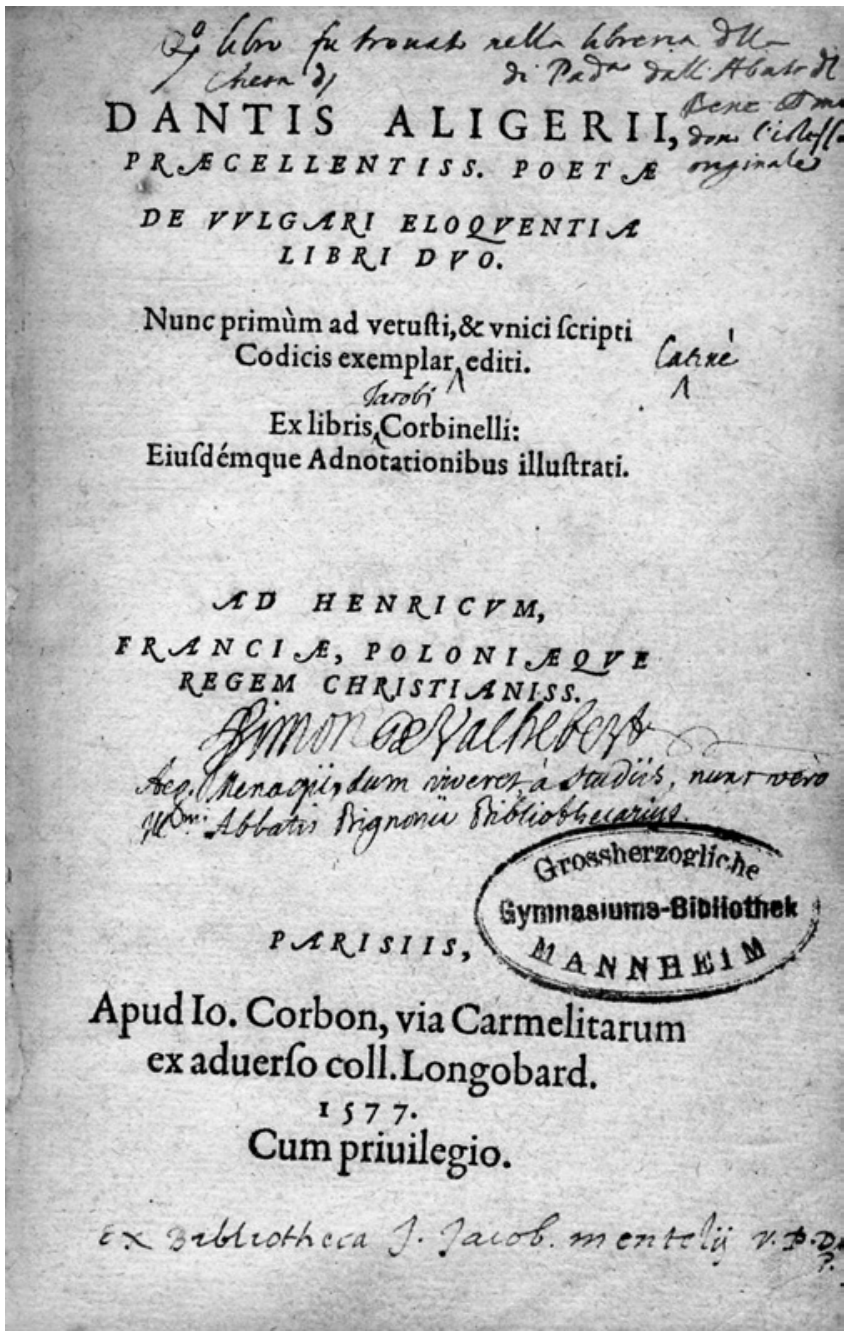

FIGURE 11.1 Dante Alighieri, Title page of De vulgari eloquentia, Paris, 1577 with manuscript notes by Gilles Ménage. University of Mannheim Sch 072/212 (http://www.uni-mannheim.de/ mateo/itali/danter/jpg/bsoor.html).

hard work of classical philology (editions of Lucretius, Propertius, Catullus, the New Testament), to edit and canonize texts which became the 'classics' of vernacular German literature, such as the poetry of Wolfram von Eschenbach and the Nibelungenlied. ${ }^{4}$ Angelo Mai discovered or rendered legible many

4 Timpanaro, La genesi del metodo del Lachmann. 
classical texts (Cicero, Plautus) by a novel treatment of palimpsests, and became the chief librarian of the Vatican Libraries; but in the process also discovered (in Milan's Ambrosian Library) important fragments of Wulfila's Gothic bible translation, thereby giving a huge boost to Germanic philology. ${ }^{5}$

As these cases already indicate, the modern vernacular philologies do not arise out of nothing, but should rather be seen as a branching-off or meiosis from classical philology. Accordingly, the use of Latin as the idiom of international learning occupies an intriguing position in the Sattelzeit. On this position I want to offer a few brief observations.

Latinitas usually connotes a trans-vernacular sphere of learning, the communicative coherence of elite networks: the medieval monasteries, church institutions, universities and academic disciplines. It had maintained itself as the working language of humanists, scholars and scientists from the renaissance throughout the seventeenth and into the early eighteenth century. Medical, legal and theological discourse still used it as a matter of course in the nineteenth century; by now it has shrunk to the liturgical use of the university (diplomas) and the Roman Catholic church.

The Sattelzeit also marks a threshold in the history of this latinitas. The modern philologies begin to use, by a tacit and implicit logic, their own root language. German grammars are written in German, French literary histories in French. (Only in certain minute philological habits does the Latinity of the discipline leave its fossilized traces: the abbreviations of the apparatus criticus, terms like manuscript, pagina, ibidem, sqq., et al., variae lectiones, anonymus.)

This transition is neither abrupt nor absolute. Certain philological works, certainly if they are of an antiquarian nature and deal with 'dead' languages, are still written in Latin, e.g. Johann Caspar Zeuss's Grammatica Celtica of 1854. Indeed, Zeuss's Celtic grammar marks the end-point of a century, roughly between 1760 and 1860 , which can be considered a transitional phase in which the investigation of vernacular cultures dovetails with the philological learning and the Latinity of established scholarly traditions rooted in the established practices of humanist and seventeenth-century scholarship.

The beginning of that transitional century is marked by the éclat of Macpherson's Ossian. ${ }^{6}$ The story is well known: how one James Macpherson, investigating oral literature in the Scottish Highlands, uncovered pieces of Gaelic poetry which were presented to the world as the fragmented remains of the fourth-century bard Ossian. These poems were first published as 'Fragments' (in 1760), and, following further fieldwork and editorial interventions, as

5 For a wider context of this philological Fachgeschichte, see Bluhm, Die Brüder Grimm, Hummel, Philologus auctor, Ridoux, Evolution des études médiévales; Turner, Philology.

6 Cf. Gaskill \& Stafford, From Gaelic to Romantic; Gaskill, The Reception of Ossian'. 
reconstituted epic lays (1767). The effect on European literature was one of widespread galvanization. Ossian immediately acquired the stature of a 'Northern Homer' (indeed, that was his current epithet) and in the years 17651790 came to be placed alongside Homer as Europe's aboriginal bard and primal genius, mainspring, not of a classical-Mediterranean tradition, but of a romantic-Nordic one.

Macpherson's procedure was in fact calqued on classical antiquarianism: in the contemporary excavations of Pompeii, many 'fragments' were coming to light, disiecta membra crunched by the ruinous passage of time, but capable of being reconstituted into the objects they once were.

The fact that the epic lays of Ossian came to be widely discredited as a fraud, a concoction by the Scottish mountebank Macpherson, did nothing to quell the wave of interest. The question remained an open one, if and how the disjointed texts of contemporary popular culture could be seen as the fragmented remains of primordial epic wholes. That historical relationship between the primal epic and its latter-day fragmented remains was placed on the historical agenda again in 1795 by a famous study, in Latin and in the mode of established classical philology, by F.A. Wolff: Prolegomena ad Homerum. Wolff accepted the fact that Ossian was no Homer; but, so he continued to cogitate, perhaps Homer himself had been a Macpherson? Thus the Ossianic Scandal morphed into the notorious Homeric Question.

In Wolff's view, Homer may have been, like Macpherson, a collector and redactor of oral, rhapsodic lays that wafted in fluid performativity across the ancient world, and which were spliced together by 'Homer' into a single largescale whole; much as Macpherson had cobbled together his Ossianic epic from dispersed oral traditions in the Scottish Highlands. That view of Homer went against Homer's established reputation as a heroic 'primitive genius', who conceived and created his epics in a single Big Bang of untaught creativity and mastery (thus for example in William Duff's Critical observations on writings of the most celebrated original geniuses in poetry (1770) and in Robert Wood's An essay on the original genius and writings of Homer, 1775$){ }^{7}$ The complexities and details of these opposed views of Homer, before and after Wolff, have been a thoroughly discussed topic among classicists, beyond my competence and my present concern. For my purpose, Wolff's importance lies in the fact that he sees epic as something that has crystallized out of, and may fragment back into, disjointed oral practices. That was a crucial working basis for the emerging generation of modern philologists.

7 Simonsuuri, Homer's Original Genius. 
The Grimm Brothers, for instance, felt that many 'trivial' forms of literature, heedlessly disregarded by those who concentrated only on the high literary canon, might have an important antiquarian importance. In the German fairytales about elves and gnomes they discerned the debased echoes of an ancient Nordic mythology. 8 The medieval satirical animal-tale of Reynart the Fox they traced back to Frankish roots and beyond that, speculatively, to ancient Germanic or Nordic epic tales about totem-animals. ${ }^{9}$ None of that would have been thinkable if it had not been for the Prolegomena ad Homerum and the idea of a cultural archeology reaching back beyond the epic emergence of a literate tradition.

Thus the prestigious method of classical antiquarianism and philology was applied to vernacular literatures, with as a result a huge rise in prestige for the non-classical traditions of Northern Europe. We can see how, in the period 1760-1860, scholars with an interest in national antiquities time and again draw on the prestige of classical philology in their investigations. Source editions, which are of enormous importance in the rediscovery of national histories, are (ironically almost) produced under Latin titles, falling back on 'best practices' established by Mabillon's diplomatics and Muratori's benchmark Rerum Italicarum scriptores. Examples from various European countries include Martin Bouquet's Rerum Gallicarum et Francicarum scriptores (1739 ff.), Jacob Langebek's Scriptores rerum Danicarum (1772); Charles O'Conor's Rerum Hibernicarum scriptores veteres (1815-1826); Erik Gustav Geijer's Scriptores rerum suecicarum medii aevi (1818-1825); Alexandre Herculano's Portugaliae monumenta historica (1856).

The most famous of these is doubtless the enormous and still ongoing enterprise of the Monumenta Germaniae Historica ( $\mathrm{MGH}$, begun in 1819$) \cdot{ }^{10}$ The organization behind it sports a heraldic motto (one of those ritual/liturgical textual outposts where Latin maintains itself), the 'seal' found on all of its publications, stating 'Sanctus amor patriae dat animum'; the sacred love of the fatherland inspires us. That invocation of amor patriae is a tell-tale indicator of shifting mentalities. It is of course a ciceronian concept, one of the classical virtues. As such it had been often invoked among the 'classical republicans' of

8 Shippey, The Shadow-Walkers.

9 Leerssen, 'A cross-country foxhunt'.

10 The famous British "Rolls Series" (so named because its nominally responsible editor is the Master of the Rolls) also follows the pattern. Its official title when it was started in 1858 was Rerum britannicarum medii aevi scriptores, and it continued a previous venture, started in 1848 in imitation of the Monumenta Germaniae Historica, entitled Monumenta Historiae Britannica. 
the Enlightenment and by that ideological movement which even derived its name from the Roman notion of patria: the Patriots. ${ }^{11}$

Tellingly, the Sattelzeit, alongside so many other shifts and transitions, sees a conceptual shift also in the political virtue of amor patriae or 'Love of the Fatherland.' ${ }^{2}$ For Enlightenment Patriots, 'love of the fatherland' meant essentially the civic virtue of being a useful member of society, and an opponent of arbitrary government, oppression and corruption. As such, semantically and politically, it was opposed to the doctrine of aristocracy, which felt that only the king and his nobility, as the elite portion of society, should be empowered to govern the state. In the United Provinces in the 1780 s, Patriots were those who opposed the power of the Prince of Orange, much as in the North American colonies, they were the opposition against the prerogatives of George III, invoking instead the rights of the people in the social contract. In the French Revolution, the two factions, aristocrats and democrats, would face each other with the mutually antagonistic slogans vive le roi and vive la patrie. ${ }^{13}$

In the nineteenth century, this societal, liberal-democratic notion of amor patriae and patriotism tilts ninety degrees. The fatherland whose rights and liberties are being defended are now no longer those of the citizens in the body politic, but those of the native country amidst other countries. The fatherland's freedom is threatened by foreign oppressors and the threat of conquest, the fatherland's identity and cohesion depend not just on a social contract but on transgenerational cultural traditions. Patriotism tilts into nationalism. The Reden an die deutsche Nation, by the prestigious German philosopher Johann Gottlieb Fichte (1808), are usually seen as a 'tipping point' in that process. Thus the motto of the MGH, invoking that 'sacred love of the fatherland', is ambivalent, harking back to a classical virtue and looking forward to a very modern ideology: nationalism. That nationalism is fed by the rediscovery of 'national classics', raising each vernacular to the status of a Major League literature, comparable to the august classics, each with its foundational source-texts much as Greece had its Homer and Rome its Laws of the Twelve Tables and its Aeneid.

One vernacular classic may count as a locus classicus for this national pride conducted through Latin: the Beowulf epic. Retrieved from oblivion in the late eighteenth century, it was first printed in Copenhagen in 1815 by the Danish scholar Thorkelin, who, tellingly, claimed the ancient text for the Danish tradition, and advanced that claim in the prestigious langue of high learning. The text appeared as a 'Poëma Danicum dialecto Anglo-Saxonica' in his De

\footnotetext{
11 Venturi, Utopia and Reform; Viroli, For Love of Country.

12 Cf. generally my National Thought in Europe.

13 Palmer, The Age of the Democratic Revolution.
} 
Danorum rebus gestis seculo III. et IV. That Thorkelin read (and of course badly misread) the Old English text as if it were written in an old form of Danish, opened the door for a century of conflicting appropriations, with English, Danish and German scholars all claiming it for their own national tradition. ${ }^{14}$

Thus latinitas became implicated, in the twilight days of its bimillennial European life-span, in the rise of vernacular nationalisms. The aforementioned Grammatica Celtica of 1854, by Zeuss, provides another telling example. Itself in the high ivory-tower mode of recondite philology, it was nevertheless implicated in the nineteenth-century trends of national thought. To begin with, it based itself on material that had become available as a result of the rise of cultural nationalism, e.g. in Ireland. It relied, not only on the scholarly groundwork of continental linguists, but also on the Rerum hibernicarum scriptores veteres by Charles O'Conor, an attempt to salvage and retrieve the lost treasures of Gaelic literature for a contemporary audience. More importantly, it drew on John O'Donovan's Irish Grammar of 1845, a key text in the run-up to the nationalist revival of the Gaelic language. ${ }^{15}$ That grammar had been written, in English, by a native speaker of Gaelic who is now heralded as one of the great cultural precursors of Irish nationalism. But not only did Zeuss draw on texts which we must situate in a context of national revivalism; in turn, too his Grammatica Celtica was itself eagerly seized upon by cultural nationalists in Ireland to prove that their native language was no mere rustic dialect but an ancient language with philological prestige and importance. Also, the English critic Matthew Arnold cited Zeuss as an example how modern scholarship could inspire a proper appreciation of the 'Anglo-Saxon' and 'Celtic' mentalities coexisting in the English national character. ${ }^{16}$

The most intriguing 'nodal point' in these developments is Jacob Grimm's inaugural lecture as Professor of German Philology at the University of Göttingen in 1830 . Grimm's reputation by 1830 stood very high indeed. Besides publishing the classic collections of fairy tales and legends, he had put German philology on a proper footing by drawing up a revolutionary German grammar on historical-comparative principles and editing important source documents

\footnotetext{
14 Shippey and Haarder, The Critical Heritage: Beowulf. More generally also Van Hulle and Leerssen, Editing the Nation's Memory.

15 Boyne, John O'Donovan; my own Remembrance and Imagination.

16 Cf. my Remembrance and Imagination and 'Englishness, Ethnicity and Matthew Arnold'.
} 
from German legal history. Both he and his brother Wilhelm accepted a call to a professorial chair in Göttingen, where they remained until $1837 .{ }^{17}$

Grimm was known as one of the great champions of his native culture, and in all his work evinced a dedication to the greatness and reputation of German letters and traditions - a dedication which is typical of the romantic nationalism of these decades. In his inaugural lecture he delivered an intellectual blueprint of his national commitment; and he delivered it in the language required of such academic rituals: Latin. This text thus provides us with an almost unique intersection in European history: the use of Latin for the purpose of a nationalist manifesto. In the process, that use of Latin becomes itself a fraught point of reflection.

The lecture is entitled De desiderio patriae. ${ }^{18}$ That Desiderium patriae translates as 'homesickness', which already alerts us to one of the crucial turns of thought in this piece. Grimm conflates the notions of desire and love, desiderium and amor, and he leads us from one to the other deliberately and purposefully. For it is amor patriae which presides over the closing sentence:

necesse est enim in tanta conversione et perturbatione rerum, qua hoc nostro tempore transitus ex recepta consuetudine in novum plane ordinem nobis portenditur, tum vigilantibus tum et dormientibus, amorem patriae caste servare, qui si manet, salvi etiam nunc esse possumus, nisi dii immortales nobis irascantur et succenseant. quapropter eo animo simus inter nos, ut decus et libertatem, ad quam nati sumus, impigre tueamur et ut oculi nobis scintillent altiusque corda palpitent, quoties dulce nomen patriae proferri audimus.

For in this time of turmoil and change through which there is forshadowed for us, whether we are aware of it or not, that passage from our traditional ways into a new order, we must hold fast the pure and holy

17 For the biographical background, see Martus, Die Brüder Grimm: Eine Biographie, esp. 332-335.

18 The text was printed in the Anzeiger für deutsches Alterhum und deutsche Literatur 7 (1881), 320-326, and in Grimm, Kleinere Schriften, 4, pp. 411-18. The full text is also online at www.spinnet.eu > resources > writings, as is the English translation by J.J. Schlicher first published in Voss and Schlicher, 'Jacob Grimm's De Desiderio Patriae'; I quote from his translation. A contemporary German summary ("Auszug aus der Rede über das Heimweh") was printed by the Göttingsche gelehrte Anzeigen at the time, doubtless provided by Grimm himself, substantiating the reading of desiderium patriae as "homesickness". In the quotation I italicize nationally evocative terms. 
love of our country, for while that love lasts we may even yet be saved, unless the anger of heaven itself should be against us. Let us then be united in the common purpose to guard like men the honor and liberty to which we are born, with eyes afire and hearts beating high whenever we hear spoken the beloved name of our native land.

Love of the fatherland for Grimm is a non-rational affect which as desiderium is a rooted in an instinctive tugging at the heartstrings. It is that love which inspires homesickness when one is abroad, and conversely homesickness, as a universal affect, proves that love of the fatherland is neither a socially inculcated political virtue nor a matter of pragmatic expedience. For that reason Grimm opens his lecture by scornfully rejecting the pragmatic nostrum (often attributed to Erasmus) ubi bene, ibi patria.

Quod communi multorum sermone teritur jactaturque, ubi bene sit, ibi patriam esse, id quidem improbe dici et nequissimum genus levitatis prodere semper mihi visum est.

The well-worn saying which we hear so often, that where we are well off there is our fatherland, has always appeared to me to express a shallow and mischievous sentiment.

On the contrary, says Grimm: love of the fatherland is wholly unlike the appreciation of useful possessions, it is the non-negotiable bond that links us to those who are close and dear to us and accompanies us throughout our life's experiences. To exemplify this affect of home-love and its concomitant homesickness as it existed in all ages and societies, Grimm does not (as might be expected) use the classic examples such as Ovid's Tristia, but lines from the ninth-century German cleric Otfrid von Weissenburg. Grimm interrupts his Ciceronian prose with a quotation in the ancient, incomprehensible Old German, without source reference or translation, as an 'in-joke' to baffle all the non-Germanists in the audience (cf. Wolff op. cit., 333). Translated, the lines read:

Oh foreign land, you are hard, You are very hard indeed, and I tell you so in truth.

Labour and strife are the lot of those away from their homeland; That I have experienced myself.

Abroad I have never found anything good or pleasant,

But only a rueful mood, a sorrowful heart, and manifold pains. 
The text then reverts to the 'more familiar' Latin... with a degree of irony which becomes apparent later on when Grimm outlines the fortunes of the German language: its primitive flourishings; its etiolation in the later Middle Ages; its restoration, consolidation and standardization achieved by Luther; and its vitiation as a result of the greater prestige of, precisely, Latin. The rise of Latinate learning, Grimm observes, diverted energies and prestige away from the cultivation of the native vernacular; and the Latin that took hold of German intellects was, as he sees it, a debased, scholastic Latin rather than the pure language of classical antiquity.

[...] haud vereor, ut vobis, auditores, displiceam, neque ut sententia mea aliter ac eam nunc aperiam a vobis accipiatur. itaque ingenue profitebor, linguae usum latinae apud majores nostras desiderio patriae diu obfuisse et quasi callum obduxisse. [...] aegre tamen patimur, primo statim tempore conversionis nostrae ad veram fidem linguam vernaculam a plurimis cultus divini officiis remotam et plane fuisse cohibitam. etenim cum clerici aliive, qui ad rempubl. administrandam adhibebantur, ecclesiastica plerumque institutione a pueris essent imbuti, consuetudo increbruit, ut non solum annales historiaeque latine conscriberentur, sed novae etiam leges in ista tantum lingua, spreta patria, conderentur et ingruenti paulatim juri romano omnes fenestrae late paterent. Quo quantum et fere irreparabile damnum linguae moribus institutisque patriis, omni paene medio aevo, illatum sit, ita apertum et manifestum est, ut invitus illud dicam. [...]

illo enim tempore lingua latina non e fonte suo limpido ac perenni hauriebatur, sed e receptaculis stagnisque aegre stillabat scriptorum ecclesiasticorum, qui ad ingenia excitanda et efformanda minimum valebant $[\ldots]$

omnibus igitur, qui ingenii essent subactioris, sermonem latinum adeo praeferentibus, ut libros in eo componerent, carmina conderent, eoque vel ad epistolas familiares uterentur, qua tandem via lingua nostra, non dico ad eloquentiam, sed ad usum interiorem formari excolique potuit?

I am $<$ not $>$ afraid that my views may perhaps be displeasing to you and may be understood in a way that I do not intend. So I shall at once freely say that the use of the Latin language by our ancestors long held back the growth of patriotic feeling, and, if I may so express myself, covered it with a thick skin. [...] we shall nevertheless regret that from the very beginning of our conversion to the true faith our own native tongue was not used in the services of the church, and even denied any share in them. 
For since the functionaries of the church and those others who were employed in the service of the State had from boyhood been educated in the church schools, it became customary to write not only chronicles and histories in Latin, but even new laws were always written in that language, with complete disregard of our own tongue, so that all doors were wide open for the gradual introduction of Roman law as well. What a great and almost irreparable damage was in this way done to our native language and to our national character and institutions during nearly the whole Middle Ages is too evident to require mention. [...] For the Latin of that time was not drawn from a clear and perennial spring, but dipped grudgingly from the standing pool of ecclesiastical writings which offered very little to stimulate and form the mind. [...] While all those who by disposition at all inclined to submit to this state of things preferred the Latin language so much that they wrote their books and composed their songs in it, how could our own language be developed and perfected, I will not say to the point of eloquence, but even for private use?

To understand this Latin attack on the use of Latin in its proper context, we should realize that Grimm's argument follows a double track. On the one hand he expounds the instinctive, universal-human nature of the emotional bond one feels with one's Heimat, experienced most sharply in the painful feelings of nostalgic homesickness when one is exiled from it, on the other hand he deduces from it a more social effect: the solidarity and bonding between fellow-nationals which is the firmest basis for social cohesion and which is cemented in the shared use of a common language.

In both respects, Grimm was following a line of argument which was of crucial importance in the development of cultural nationalism as it took place in early-nineteenth-century Germany, and in both respects Grimm is echoing (albeit without overt acknowledgement) the ideology outlined by his older contemporaries Johann Gottlieb Fichte and Ermst Moritz Arndt. Both had resisted the values of the French Revolution (transmogrified into napoleonic rule) by redefining the idea of nationality and love of the fatherland.

Whereas 'the nation' for Rousseau and the French constitutionalists was a social contract, and therefore defined primarily in the class-transcending solidarity of all those sharing the framework of a society and economic system, Fichte (in the aforementioned Reden an die deutsche Nation) saw the nation primarily in terms of the filiation between generations, and the moral-cultural contract between ancestors and descendants. In thus shifting the notion of nationality from the synchronic to the diachronic, from the civic to the ethnic, Fichte already drew on a moral category to demonstrate his point: the selfless, 
untaught, unpremeditated, instinctive and universal love between parents and children. This fundamentally human affect manifests an interpersonal and intergenerational solidarity and thus demonstrates (so Fichte argued) that nationality is an inborn pre-given rather than a political doctrine. Thence, Fichte deduced that to maintain an unbroken continuity (i.e. cultural loyalty to one's national identity) from ancestors to descendants was an imperative both moral and political. Hence, again, the Germans, who had stuck to their language and traditions, were a more authentic, and as such a morally superior, nation compared to those who had in the course of history given up their tribal languages and institutions for the heritage of ancient Rome (Roman law, Romance languages). That line of reasoning, from human affects to a chauvinistic proclamation of the moral superiority of the German nation over others, is echoed step by step by Grimm. ${ }^{19}$

The other presiding genius behind Grimm's position is Ernst Moritz Arndt. What is peculiar to Arndt's German propaganda is that he extends the cultural argument to the territory occupied by the state. That, too, is a novelty in the ideological developments of these Sattelzeit decades: the territorialization of culture. Arndt argues that the shape and demarcation of a reconstituted Germany should include all lands whose inhabitants historically belonged to the complex of German culture. The most widely effective propaganda medium in which he disseminated this notion was the 1813 song 'Was ist des Deutschen Vaterland?' ('What is the German's fatherland?'), which from stanza to stanza surveys the regions from Alps to North Sea, to conclude in each case that the German's fatherland is greater than each separate region. Finally the answer to the title question is given:

What is the German's fatherland? Name it to me then, at last!

- As far as the German tongue is heard singing the praise of God in heaven

That, bold German, you may call yours!

In many political tracts, Arndt used this principle to claim contested borderlands for a greater, inclusive Germany. ${ }^{20}$ The Swiss Cantons, the Rhine Valley, Flanders, Alsace-Lorraine and Schleswig-Holstein by this definition were all legitimate German claims. Arndt's mode of substitutive reasoning (the state should be constituted by the constituent nation, that nation is defined by its

19 It should be added that Grimm's historicism also derived from his erstwhile law professor and mentor at Marburg, Friedrich Carl von Savigny.

20 Cf. my De bronnen van het vaderland. 
language, therefore the state's territorial footprint should be the that of the language area) has become deeply ingrained in European nationalism and has caused untold mischief in those many borderlands and transition zones which are linguistically mixed and which have therefore been claimed by competing adjacent states. Be that as it may, we see that Grimm himself follows the same line of substitution. The fatherland is that place where we are embedded in the kinship-solidarity of our fellow-nationals, as manifested in the fact that we speak the same language. And Grimm concludes with a sentence that might almost be a Latin paraphrase of Arndt's 'Was ist des Deutschen Vaterland':

Linguam vero patriam, quae summum firmamentum reip. est, indefesse colamus perpoliamusque, et quam late illa vigeat, tam late Germaniam extendi non dubitemus.

But in our own language which is the surest foundation upon which our state can rest, we must cultivate and perfect, and not doubt [that, as far and wide as it thrives, thus far Germany extends].21

In all these respects, Grimm's inaugural lecture is a brilliantly condensed position paper by one of the leading philologists and cultural nationalists of his time. In the climate of 1830 , it looks forward, indeed, to a transitus ex recepta consuetudine in novum ordinem ('a transition from tradition to a new order') which was to lead, ultimately, to Germany's unification, to the idea of the nation-state and the nation's right to self-determination, and to bitter wars between those nations all vehemently supported by the nativist and xenophobic amor patriae of their citizens. That this fateful message should have been proclaimed in the language of Erasmus is one of the great ironies of Europe's cultural history.

21 Here, the translation of the closure does not follow that of Schlicher (note 18), who gives: "that the limits of its life and power will also be the boundaries of Germany itself"; that translation abandons verbal fidelity and loses the Arndt echo, which is why I have substituted my own rendition. 